\title{
MECHANICAL AND PHYSICAL PROPERTIES OF MEDIUM DENSITY FIBREBOARD WITH CALCITE ADDITIVE
}

\author{
Osman Camlibel \\ Kirikkale University \\ Yahsihan/ KirikKale, Turkey \\ Mehmet Akgul \\ Karamanoglu Mehmetbey University \\ Karaman, Turkey \\ (Received May 20I9)
}

\begin{abstract}
In this study, it is investigated that are calcite filler can be used in the production of medium density fiberboard. Chips have been to the process of cooking for 4-5 minutes in Asplund defibrator with the vapor pressure of $7-7.5$ bar, and $180^{\circ} \mathrm{C}$ temperature. $1.5 \%$ paraffin and $1 \%$ ammonium sulphate to be pulverized is added to fibers on the output of defibrillator and blowline line. Calcite fillers are prepared in a separate tank in order to use calcite instead of lignocellulosic fibers in the production of $1 \mathrm{~m}^{3} \mathrm{MDF}$. After that, urea formaldehyde glue is prepared as three different solutions which include the calcite, respectively with $3 \%\left(20 \mathrm{~kg} \cdot \mathrm{m}^{-3}\right), 6 \%\left(40 \mathrm{~kg} \cdot \mathrm{m}^{-3}\right)$, $9 \%\left(60 \mathrm{~kg} \cdot \mathrm{m}^{-3}\right)$. The fibers are dried to moisture of $8 \%-12 \%$. This press applies temperature about $185-190^{\circ} \mathrm{C}$ and pressure about $32-34 \mathrm{~kg} \cdot \mathrm{m}^{-2}$ to the mixture material for 270 seconds during pressing time. MDF panels $(2100 \times 4900$ x $18 \mathrm{~mm}$ ) were produced in the process. Both mechanical and physical experiments are performed on boards which are produced.
\end{abstract}

KEYWORDS: MDF, fiberboard, calcite filler, physical properties, mechanical properties.

\section{INTRODUCTION}

The wood chips or lignocellulosic materials, cement, water and chemicals can be produced as smooth-surfaced panels by mixing in suitable proportions in forest products industry. Wood composite products with binding calcite materials were generated by using plaster, magnesium cement and Portland cement. Güller (2001) has produced the calcite material-binding fiber boards and particle boards. Kalaycıŏlu et al. (2012) have performed some studies on the cement composites and wood wool. Salari et al. (2012) have produced the OSB board which had added 
nanoclays layered silicates as reinforced adhesive with $0 \%, 2 \%, 4 \%, 6 \%, 8 \%$ mixing ratios. They have also performed studies on the physical and mechanical properties. Candan et al. (2012) have investigated the effects of some production parameters on the layer thickness swell properties of the medium density fibreboard (MDF). Özdemir and Ayaz (2017) have investigated the effect of ammonium polyphosphate (app) and boric acid (BA) on the fire resistance of MDF panels as surface coating material. Zahedsheijani et al. (2011) studied the potential use of Nanoclay in MDF production. Özdemir (2019) has produced three different minerals (sepiolite, dolomite and perlite) and five different ratios (3\%, 6\%, 9\%, $12 \%$ and 15\%) according to the oven-dry wood fiber weight. Taghiyari et al. (2016) have produced MDF from wollastonite fibers, camel-thorn and wood fibers. They have studied the physical and mechanical properties of these boards. Taghiyari and Nouri (2015) have investigated nano-wollastonite (NW) on physical and mechanical properties of medium density fiberboard (MDF). Wang et al. (2016) produced vermiculite added MDF boards. They have investigated the properties of boards, limitation of oxygen index (LOI), simultaneous thermal analysis (TG-DSC), the modulus of rupture (MOR), and the modulus of elasticity (MOE). Akgül et al. (2017) have produced agribased lignocellulosic biomass (okra, tobaccos, hazelnut, walnuts hell, pine cone) in medium density fiberboard (MDF) production. They have investigated on physical and mechanical properties of medium density fiberboard (MDF). Kaya (2018) has investigated the physical and mechanical properties of fiber layers produced by using glass fiber mixture of walnut shells and sunflower stalks in different ratios were investigated. Ozdemir (2019) have investigated the use of different mineral material types (sepiolite, dolomite, and perlite) in medium density fiberboard (MDF) production. Çavdar et al. (2019) have investigated ammonium zeolite and ammonium phosphate as fire retardants for microcrystalline cellulose thermoplastic composites. Funk et al. (2017) have studied diatomaceous earth as an inorganic additive to reduce formaldehyde emissions from particleboards. Istek et al. (2013) have worked combustion properties of medium-density fiberboards coated by a mixture of calcite and various fire retardants. Özdemir et al. (2016) have researched the effects of coating with calcite together with various fire retardants on the fire properties of particleboard.

These researchers were about the possibilities of use of the calcite minerals instead of lignocellulosic raw materials. There are millions of tons of the calcite mineral reserves in Turkey. In MDF production process the calcite mineral, which has the mixing ratio $0 \%, 3 \%, 6 \%, 9 \%$, was produced for boards in industrial process scale.

The production of MDF in 2015 was about 5,412.0 million $\mathrm{m}^{3}$ in Turkey. The production of MDF in 2015 was about 98,098.0 million cubic meters/year in the world. In this study, the experimental investigations handled in order to realize the density and physical and mechanical properties of the produced boards which have calcite mineral according to the control board.

\section{MATERIAL AND METHODS}

\section{Materials}

Beech (Fagus orientalis L.) from Duzce province forestry, Oak (Quercus Robur L.) from the West Black Sea region and pine (Pinus sylvestris L) from Bolu province were supplied for the production of MDF. Calcite consists of $90 \% \mathrm{CaCO}_{3}$ containing limestone with hardness and the specific gravity $2.5-2.7 \mathrm{~g} \cdot \mathrm{cm}^{-3}$ was provided from the region about the province of Aksaray. Calcium oxide is converted into calcium hydroxide by reaction with water. The urea formaldehyde resins, the liquid paraffin and the ammonium sulphate were supplied from Polisan company in Gebze, Mercan Chemistry in Denizli and another company in Gebze, respectively. 


\section{Methods}

The solid ratio of the urea-formaldehyde is reduced to $50 \%$ solid rate in the production process. The colour of ammonium sulfate crystal grains is off-white. It is prepared for hardener with $20 \%$ solution, and then it is injected from a single point to blow line. The colour of liquid paraffin is cream and the fat content is up to $2 \%$. The penetration of liquid paraffin is 32 , and then it is stored in reserve tank as liquid state. The liquid paraffin is mixed into dry fiber up to a maximum of $1.5 \%$ percent. The mixture described above is added to fiber in Asplund defibrator. The hardener, calcite solution and urea-formaldehyde are injected from blow line to the biomass fiber.

Fibers, which include the calcite and the chemical, are dried at the drier line up to $11-12 \%$ of moisture. Dried fibers are made up of mat in the mechanical station. The mat is produced by pressing in the multi hot press. The pressing parameters are $180-190^{\circ} \mathrm{C}, 32-34 \mathrm{~kg} \cdot \mathrm{m}^{-2}$ and 275 second. The dimensions of the panel are $2100 \times 4900 \times 18 \mathrm{~mm}$. After production of the panels in process, the panels are leaved to rest in pre-storage for 5 days. The panels are acclimatized here. The moisture level is adjusted to $7.5 \%$. After this process, the top and bottom surfaces of panels are sanded with 40, 80, 120 grit size sandpaper.Then all panels were conditioned at $20+2{ }^{\circ} \mathrm{C}$ and $65+5 \%$ relative humidity until $12 \%$ moisture content was reached. The MDF product process is presented in Fig. 1.

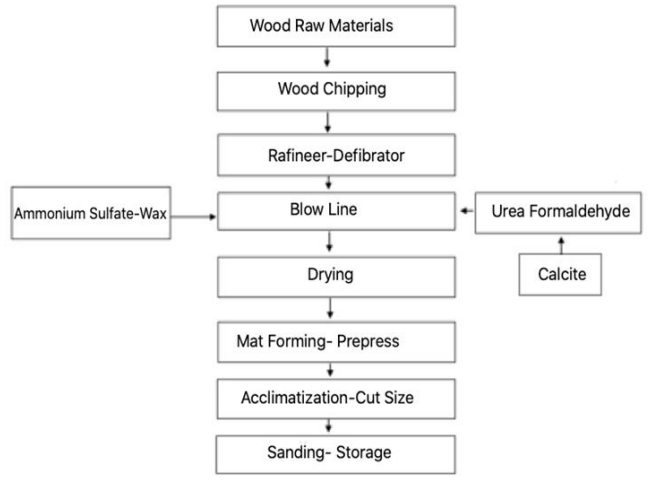

Fig. 1: Product process flow.

The resins and other chemicals are prepared in the glue unit. The calcite mineral solution is prepared in the solution preparing tank. After that these chemicals, which are prepared in the tank, are mixed with each other and this mixture is sent blow line.

\section{Product parameters}

Wood fiber contains $70 \%$ hardwoods and 30\% softwood fibers in this study. Firstly, the hardwood and softwood species had brought from the Western Black Sea forests, and then these species were chopped and stored one by one in silos according to the production parameters. In Tab. 1, R defines the consumed wood fibers for $1 \mathrm{~m}^{3}$ board, $\mathrm{C}$ defines the consumed calcite minerals for $1 \mathrm{~m}^{3}$ board. The raw materials formulation for the experimental MDF boards are presented in Tab. 1. This table shows the addition of calcite solution and other chemicals to lignocellulosic biomass. Xing et al. (2006) in a study in MDF production; The effect of wood acidity has been shown to have a direct effect on the gel time and curing behavior of UF resins. In this study; the amount of calcite had no significant effect on the curing of the glue. 
Tab. 1: Experimental design.

\begin{tabular}{|c|c|c|c|c|c|c|c|c|}
\hline Board & Product & \multirow{2}{*}{ Biomass } & \multirow{2}{*}{ Resin } & \multirow{2}{*}{ Hardener } & \multirow{2}{*}{ Paraffin } & Calcite & Industrial & \multirow{2}{*}{ Ratio } \\
\cline { 1 - 1 } Type & Type & & & & & filler & fibers & \\
\hline $\mathrm{R}_{100} \mathrm{C}_{0}$ & MDF & $\mathrm{L}$ & UF & AS & Wax & 0 & $100 \%$ & 0 \\
\hline $\mathrm{R}_{97} \mathrm{C}_{3}$ & MDF & $\mathrm{L}$ & $\mathrm{UF}$ & $\mathrm{AS}$ & Wax & $\mathrm{C}$ & $97 \%$ & $3 \%$ \\
\hline $\mathrm{R}_{94} \mathrm{C}_{6}$ & MDF & $\mathrm{L}$ & $\mathrm{UF}$ & $\mathrm{AS}$ & Wax & $\mathrm{C}$ & $94 \%$ & $6 \%$ \\
\hline $\mathrm{R}_{91} \mathrm{C}_{9}$ & MDF & $\mathrm{L}$ & $\mathrm{UF}$ & $\mathrm{AS}$ & Wax & $\mathrm{C}$ & $91 \%$ & $9 \%$ \\
\hline
\end{tabular}

R: fiber content. MDF: medium density fibreboard, L:lignocellulosic, UF:urea formaldehyde, AS: ammonium sulphate, C:calcite.

\section{Hot multiple press parameters}

The MDF production hot press diagram is presented in Fig. 2.

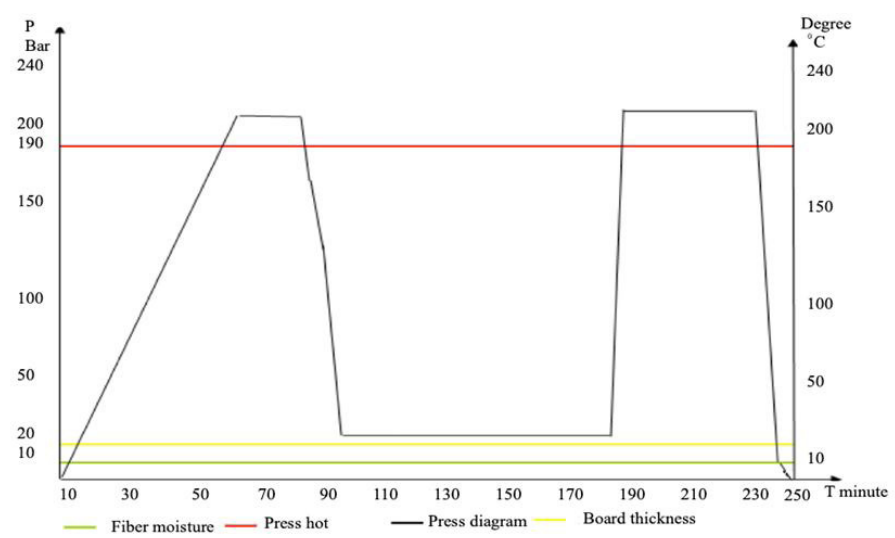

Fig. 2: Press diagram.

\section{Glue}

The urea-formaldehyde glue with the following technical specification was used: solid (65\%), formaldehyde / urea molar ratio $(1.25)$, density at $20^{\circ} \mathrm{C}\left(1.227 \mathrm{~g} \cdot \mathrm{cm}^{-3}\right)$, viscosity $20 \mathrm{cPs}$ (185 second), gel time $100^{\circ} \mathrm{C}, 20 \%$ (NH4)2SO4: (25-40 sec), $\mathrm{pH}$ (7.5 to 8.5), free formaldehyde content $0.5 \%$ max, methylol groups $12-15 \%$, average shelf life is 45 days.

\section{Physical testing}

Physical properties were tested according to TS-EN 622-5 (2008) and the density of MDF sheets was tested according to TS-EN-323 (1999). The water absorption and thickness swelling of the specimens were measured according to TS-EN 317 (2008). The sheet surface toluene was tested TS according to the EN 382-1 (1999). Sample thickness and length of specimens were measured by using a digital micrometer and caliber with $0.01 \mathrm{~mm}$ gradients.

\section{Colour properties}

Colour measurements are measured by using the tristimulus photoelectric colorimeter Elrepho Spectrophotometer, with a measuring head $50 \mathrm{~mm}$ in diameter, according to ASTM D2244-07e1 standards. The Elrepho spectrophotometer measures the colour of any material in a three-dimensional colour area. This system is called CIE L*a*b* and works according to the 
CIE Standard. The part of the coordinate system, which is interested in this work, is the first quadrant which corresponds positive values of $a^{*}$ and $b^{*}$. The colour parameters $L^{*}, a^{*}$, and $b^{*}$ were determined by the CIEL* $\mathrm{a}^{*} \mathrm{~b}^{*}$ method on the surface fiberboards. Their variations with regard to the treatment $\left(\Delta \mathrm{L}^{*}, \Delta \mathrm{a}^{*}, \Delta \mathrm{b}^{*}\right)$ are calculated. The colour sphere is defined as the circle of the crosssection at $\mathrm{L}^{*}=50$. The colour difference, $\Delta \mathrm{E}$ total colour difference is the distance between two colour points in the colour sphere. To the right: Cross section at $\mathrm{L}^{*}=50$ showing the axis from green to red $\left(\mathrm{a}^{*}\right)$ and from blue to yellow $\left(\mathrm{b}^{*}\right)$, the coordinates chroma $\left(\mathrm{C}^{*}\right)$ and hue $(\mathrm{h}=\arctan$ $\left.\left(\mathrm{b}^{*} / \mathrm{a}^{*}\right)\right)$ is the hues of a colour: 0 or 360 is red, 90 is yellow, 180 is green and 270 is blue. $\mathrm{L}^{*}$ is the lightness; $100=$ white and $0=$ black. $C^{*}$ is the chroma or saturation; 0 represents only greyish colours and 60 (Akgül 2013). The three measured co-ordinates, $\mathrm{L}^{*}, \mathrm{a}^{*}$, and $\mathrm{b}^{*}$, were transformed to $\mathrm{L}^{*}, \mathrm{C}^{*}$, and $\mathrm{h}$ co-ordinates and $\Delta \mathrm{E}$ values, according to the Eq. 1 (Temiz et al. 2005)

$$
\Delta E=\sqrt{(\Delta L)^{2}+(\Delta a)^{2}+(\Delta b)^{2}}
$$

The $L^{*} C^{*} b$ system has been chosen, since only one color variable is needed to donate hue, i.e. red, green, blue, or yellow and furthermore, this system is easy to refer to our experience of colour characteristics such as lightness, saturation, and hue. Each colour parameter L*, $\mathrm{C}^{*}, \mathrm{~h}$ and $\Delta \mathrm{E}$, was measured for each material, time, and temperature. The average colour values, standard deviations, and 5\% significance level based on distribution were calculated assuming normal distribution. The lower value of $\Delta \mathrm{E}^{*}$ indicates that the colour is either not changed or the change is negligible equation (Akgül 2013).

\section{Mechanical testing}

Cutting and sizing according to TS EN 325 (2008), TS EN 326-1 (1999) standard has been performed to specify the properties of MDF sheets with calcite. These tests were; bending strength TS EN 310 (2008), modulus elasticity TS EN 310 (2008), internal bond TS EN 319 (2008). Screw holding ability perpendicular to the plane of panel ASTM D 1037-78 (1994). An universal tester (imal mobiltemp shc22, model ib400) was used to assess mechanical properties. Janka hardness measure vertically to the sheet surface standards have been applied ANSI A 208.1 (1999).

\section{Statistical analysis}

The data concernings physical tests, colour feature tests, mechanical tests were explained \pm standard deviation and were analyzed using an analysis of variance (ANOVA) method for a entirely completely randomized design. Differences were considered statistically substantial at $\mathrm{p}<0.05$. As a result of these tests, SPSS 17 (ANOVA) Duncan results are evaluated by statistical programs.

\section{RESULTS AND DISCUSSION}

The results of ANOVA and Duncan mean separation test for density, the toluene surface, the thickness swelling (TS, 2-24 hours) and water absorption (WA, 2-24 hours) percent of the fiberboards made from calcite addictive fiber and control fiberboards are shown in Tab. 2. 
Tab. 2: The results of ANOVA and Duncan mean separation test for density, the toluene surface, the thickness swelling (TS, 2-24 hours) and water absorption (WA, 2-24 hours) percent of the fiberboards made from calcite addictive fiberboards and control fibreboard.

\begin{tabular}{|c|c|c|c|c|c|c|c|}
\hline \multirow{2}{*}{\multicolumn{2}{|c|}{$\begin{array}{l}\text { Board } \\
\text { Calcite }\end{array}$}} & \multirow{2}{*}{ Avg. ${ }^{x}$} & Std. & \multirow{2}{*}{\multicolumn{2}{|c|}{$\begin{array}{c}\text { Board } \\
\text { Calcite }\end{array}$}} & \multirow{2}{*}{ Avg. ${ }^{x}$} & \multirow{2}{*}{$\begin{array}{c}\text { Std. } \\
\text { Deviation }\end{array}$} \\
\hline & & & Deviation & & & & \\
\hline \multirow{4}{*}{$\begin{array}{l}\text { Density } \\
\left(\mathrm{gr} \cdot \mathrm{cm}^{-3}\right)\end{array}$} & $\mathrm{R}_{100} \mathrm{C}_{0}$ & $0.715^{\mathrm{a}}$ & 0.01 & \multirow{4}{*}{$\begin{array}{c}\text { TS } 2 \text { hours } \\
(\%)\end{array}$} & $\mathrm{R}_{100} \mathrm{C}_{0}$ & $3.81^{\mathrm{a}}$ & 0.40 \\
\hline & $\mathrm{R}_{97} \mathrm{C}_{3}$ & $0.720^{\mathrm{a}}$ & 0.02 & & $\mathrm{R}_{97} \mathrm{C}_{3}$ & $8.44^{\mathrm{b}}$ & 1.82 \\
\hline & $\mathrm{R}_{94} \mathrm{C}_{6}$ & $0.716^{\mathrm{a}}$ & 0.02 & & $\mathrm{R}_{94} \mathrm{C}_{6}$ & $11.09^{c}$ & 0.98 \\
\hline & $\mathrm{R}_{91} \mathrm{C}_{9}$ & $0.712^{\mathrm{a}}$ & 0.01 & & $\mathrm{R}_{91} \mathrm{C}_{9}$ & $13.15^{\mathrm{d}}$ & 1.00 \\
\hline \multirow{4}{*}{$\begin{array}{c}\text { WA } 2 \text { hours } \\
(\%)\end{array}$} & $\mathrm{R}_{100} \mathrm{C}_{0}$ & $21.29^{\mathrm{a}}$ & 2.00 & \multirow{4}{*}{$\begin{array}{c}\text { TS } 24 \text { hours } \\
(\%)\end{array}$} & $\mathrm{R}_{100} \mathrm{C}_{0}$ & $10.55^{\mathrm{a}}$ & 0.28 \\
\hline & $\mathrm{R}_{97} \mathrm{C}_{3}$ & $33.93^{\mathrm{b}}$ & 3.99 & & $\mathrm{R}_{97} \mathrm{C}_{3}$ & $16.88^{b}$ & 1.01 \\
\hline & $\mathrm{R}_{94} \mathrm{C}_{6}$ & $36.61^{b}$ & 4.56 & & $\mathrm{R}_{94} \mathrm{C}_{6}$ & $18.28^{\mathrm{c}}$ & 0.22 \\
\hline & $\mathrm{R}_{91} \mathrm{C}_{9}$ & $39.91^{\mathrm{c}}$ & 7.51 & & $\mathrm{R}_{91} \mathrm{C}_{9}$ & $20.51^{\mathrm{d}}$ & 0.85 \\
\hline \multirow{4}{*}{$\begin{array}{c}\text { WA } 24 \\
\text { hours (\%) }\end{array}$} & $\mathrm{R}_{100} \mathrm{C}_{0}$ & $41.68^{\mathrm{a}}$ & 2.86 & \multirow{4}{*}{$\begin{array}{l}\text { BST } \\
(\mathrm{cm})\end{array}$} & $\mathrm{R}_{100} \mathrm{C}_{0}$ & $34.35^{\mathrm{a}}$ & 1.08 \\
\hline & $\mathrm{R}_{97} \mathrm{C}_{3}$ & $70.29 \mathrm{~b}$ & 10.13 & & $\mathrm{R}_{97} \mathrm{C}_{3}$ & $31.00^{\mathrm{b}}$ & 1.29 \\
\hline & $\mathrm{R}_{94} \mathrm{C}_{6}$ & $70.67 \mathrm{~b}$ & 6.52 & & $\mathrm{R}_{94} \mathrm{C}_{6}$ & $29.00^{c}$ & 1.45 \\
\hline & $\mathrm{R}_{91} \mathrm{C}_{9}$ & $80.29^{c}$ & 7.41 & & $\mathrm{R}_{91} \mathrm{C}_{9}$ & $25.00^{\mathrm{d}}$ & 2.47 \\
\hline
\end{tabular}

$\mathrm{x}$ - the average value of the samples, 95\% confidence interval for the average ANOVA. a, b, c, d- values with the same letter are not significantly different (Duncan's test), (TS) thickness swelling, (WA) water absorption, (BST) board surface test.

The conclusions are shown in Tab. 2. There is no significant difference between densities for calcite added panels $\mathrm{R}_{100} \mathrm{C}_{0}, \mathrm{R}_{97} \mathrm{C}_{3}, \mathrm{R}_{94} \mathrm{C}_{6}, \mathrm{R}_{91} \mathrm{C}_{9}$ according to this statistical analysis result. The results of MDF densities stay in $0,65<\mathrm{MDF}<0,80 \mathrm{~g} \cdot \mathrm{cm}^{-3}$ according to TS EN 622-5 standards. Thus, there is no significant difference in results.

The ratio of the lowest fiberboard density to the average fiberboard density is always desired between 0.85 to 0.95 values. The efficiency of process parameters and applied hot press diagram in MDF production affect the optimum homogenous density of the fiberboard.

\section{The results of the swell in water for 2 hours test}

There is significantly difference between $\left(\mathrm{R}_{100} \mathrm{C}_{0}\right),\left(\mathrm{R}_{97} \mathrm{C}_{3}\right),\left(\mathrm{R}_{94} \mathrm{C}_{6}\right)$ and $\left(\mathrm{R}_{91} \mathrm{C}_{9}\right)$ according to the percentage of swell in water for 2 hours test. The results are explained in Tab. 2. The ratio for this test is $121.3 \%$ for $\mathrm{R}_{97} \mathrm{C}_{3}$ according to $\mathrm{R}_{100} \mathrm{C}_{0}$. Therefore, the percentage of swelling increases for $\mathrm{R}_{97} \mathrm{C}_{3}$. Similarly, the ratio is $190.6 \%$ for $\mathrm{R}_{94} \mathrm{C}_{6}$ according to $\mathrm{R}_{100} \mathrm{C}_{0}$. Therefore, the percentage of swelling increases for $\mathrm{R}_{94} \mathrm{C}_{6}$. The ratio is $244.7 \%$ for $\mathrm{R}_{91} \mathrm{C}_{9}$ according to $\mathrm{R}_{100} \mathrm{C}_{0}$. Therefore, the percentage of swelling increases for $\mathrm{R}_{91} \mathrm{C}_{9}$. The thickness swelling and water absorption properties of the test panels increased as the amount of mineral filler usage was increased (Özdemir, 2019).

\section{The results of the swell in water for 24 hours test}

There is significantly difference between $\left(\mathrm{R}_{100} \mathrm{C}_{0}\right),\left(\mathrm{R}_{97} \mathrm{C}_{3}\right),\left(\mathrm{R}_{94} \mathrm{C}_{6}\right)$ and $\left(\mathrm{R}_{91} \mathrm{C}_{9}\right)$ according to the percentage of swell in water for 24 hours test. The results are explained in Tab. 2. The ratio for this test is $60.0 \%$ for $\mathrm{R}_{97} \mathrm{C}_{3}$ according to $\mathrm{R}_{100} \mathrm{C}_{0}$. Therefore, the percentage of swelling increases for $\mathrm{R}_{97} \mathrm{C}_{3}$. Similarly, the ratio is $73.2 \%$ for $\mathrm{R}_{94} \mathrm{C}_{6}$ according to $\mathrm{R}_{100} \mathrm{C}_{0}$. Therefore, the percentage of swelling increases for $\mathrm{R}_{94} \mathrm{C}_{6}$. The ratio is $94.4 \%$ for $\mathrm{R}_{91} \mathrm{C}_{9}$ according to $\mathrm{R}_{100} \mathrm{C}_{0}$. Therefore, the percentage of swelling increases for $\mathrm{R}_{91} \mathrm{C}_{9}$. 


\section{The results of the water absorption for 2 hours test}

There is significant difference between $\left.\left(\mathrm{R}_{100} \mathrm{C}_{0}\right), \mathrm{R}_{97} \mathrm{C}_{3}, \mathrm{R}_{94} \mathrm{C}_{6}\right)$ and $\left(\mathrm{R}_{91} \mathrm{C}_{9}\right)$ according to the percentage of the water absorption for 2 hours test. The results are explained in Tab. 2. The ratio for this test is $59.3 \%$ for $\mathrm{R}_{97} \mathrm{C}_{3}$ according to $\mathrm{R}_{100} \mathrm{C}_{0}$. Therefore, the percentage of water absorption increases for $R_{97} C_{3}$. Similarly, the ratio is $71.9 \%$ for $R_{94} C_{6}$ according to $R_{100} C_{0}$. Therefore, the percentage of the absorption increases for $\mathrm{R}_{94} \mathrm{C}_{6}$. The ratio is $87.4 \%$ for $\mathrm{R}_{91} \mathrm{C}_{9}$ according to $\mathrm{R}_{100} \mathrm{C}_{0}$. Therefore, the percentage of the absorption increases for $\mathrm{R}_{91} \mathrm{C}_{9}$.

\section{The results of the water absorption for 24 hours test}

There is a significant difference between $\left(\mathrm{R}_{100} \mathrm{C}_{0}\right),\left(\mathrm{R}_{97} \mathrm{C}_{3}, \mathrm{R}_{94} \mathrm{C}_{6}\right)$ and $\left(\mathrm{R}_{91} \mathrm{C}_{9}\right)$ according to the percentage of the water absorption for 24 hours test. The results are explained in Tab. 2. The ratio for this test is $68.6 \%$ for $\mathrm{R}_{97} \mathrm{C}_{3}$ according to $\mathrm{R}_{100} \mathrm{C}_{0}$. Therefore, the percentage of the water absorption increases for $\mathrm{R}_{97} \mathrm{C}_{3}$. Similarly, the ratio is $69.6 \%$ for $\mathrm{R}_{94} \mathrm{C}_{6}$ according to $\mathrm{R}_{100} \mathrm{C}_{0}$. Therefore, the percentage of the absorption increases for $\mathrm{R}_{94} \mathrm{C}_{6}$. The ratio is $92.6 \%$ for $\mathrm{R}_{91} \mathrm{C}_{9}$ according to $\mathrm{R}_{100} \mathrm{C}_{0}$. Therefore, the percentage of the absorption increases for $\mathrm{R}_{91} \mathrm{C}_{9}$. This increase in the thickness swelling and water absorption properties of the boards was due to the material properties of the mineral materials such as hydrophilic properties (Özdemir 2019). It shows that as the resin content increases, mat moisture content increases and continuous press speed increases, the TS values of MDF panels decrease both for 2 hours and 24 hours (Candan et al. 2012).

\section{The results of toluene on the surface of board test}

There is a significant difference between $\left(\mathrm{R}_{100} \mathrm{C}_{0}\right),\left(\mathrm{R}_{97} \mathrm{C}_{3}\right),\left(\mathrm{R}_{91} \mathrm{C}_{9}\right)$ and $\left(\mathrm{R}_{94} \mathrm{C}_{6}\right)$ according to the percentage of toluene on the surface of board test. The results are explained in Tab. 2. The ratio for this test decreases $10.8 \%$ for $\mathrm{R}_{97} \mathrm{C}_{3}$ according to $\mathrm{R}_{100} \mathrm{C}_{0}$. Therefore, the percentage of toluene on the surface of board decreases for $\mathrm{R}_{97} \mathrm{C}_{3}$. Similarly, the ratio decreases $18.4 \%$ for $\mathrm{R}_{94} \mathrm{C}_{6}$ according to $\mathrm{R}_{100} \mathrm{C}_{0}$. Therefore, the percentage of the absorption decreases for $\mathrm{R}_{94} \mathrm{C}_{6}$. The ratio is $37.4 \%$ for $\mathrm{R}_{91} \mathrm{C}_{9}$ according to $\mathrm{R}_{100} \mathrm{C}_{0}$. Therefore, the percentage of the absorption increases for $\mathrm{R}_{91} \mathrm{C}_{9}$. The physical properties of the fiber boards are determined according to the raw material source, quantity and type of additives, resin ratio and press conditions produce in MDF boards (Kaya, 2018). The addition of inorganic filler to the MDF changes the WA and TS of the boards significantly. In fact, the results indicate that the addition of filler might increase WA and TS, which is considering the fact that some parts of hydrophilic wood fibers were exchanged by the inorganic mineral. Owing to the increase in the amount of calcite filling between wood fibers, the bond of wood fibers with each other are decreasing.

\section{Color properties}

ASTM D2244-07el standard is applied in this test. The surface color analysis of MDF fiberboards is calculated by using Eq. 1. The results are explained in Tab. 3. 
Tab. 3: ANOVA and Duncan average separation test results of surface color analysis of MDF fiberboards.

\begin{tabular}{|c|c|c|c|c|c|c|c|}
\hline \multirow{2}{*}{\multicolumn{2}{|c|}{$\begin{array}{c}\text { Board Type } \\
\text { Calcite }\end{array}$}} & \multirow{2}{*}{ Avg.x } & Std. & \multirow{2}{*}{\multicolumn{2}{|c|}{$\begin{array}{c}\text { Board Type } \\
\text { Calcite }\end{array}$}} & \multirow{2}{*}{ Avg.x } & Std. \\
\hline & & & Deviation & & & & Deviation \\
\hline \multirow{4}{*}{$\Delta \mathrm{Ly}$} & $\mathrm{R}_{100} \mathrm{C}_{0}$ & $60.47^{\mathrm{a}}$ & 0.95 & \multirow{4}{*}{$\Delta \mathrm{bt}$} & $\mathrm{R}_{100} \mathrm{C}_{0}$ & $20.28^{a}$ & 0.38 \\
\hline & $\mathrm{R}_{97} \mathrm{C}_{3}$ & $59.38^{\mathrm{b}}$ & 0.44 & & $\mathrm{R}_{97} \mathrm{C}_{3}$ & $18.10^{\mathrm{b}}$ & 0.38 \\
\hline & $\mathrm{R}_{94} \mathrm{C}_{6}$ & $61.26^{\mathrm{a}}$ & 2.05 & & $\mathrm{R}_{94} \mathrm{C}_{6}$ & $18.6^{\mathrm{b}}$ & 0.38 \\
\hline & $\mathrm{R}_{91} \mathrm{C}_{9}$ & $62.64^{\mathrm{c}}$ & 1.53 & & $\mathrm{R}_{91} \mathrm{C}_{9}$ & $19.96^{\mathrm{a}}$ & 0.38 \\
\hline \multirow{4}{*}{$\Delta \mathrm{az}$} & $\mathrm{R}_{100} \mathrm{C}_{0}$ & $5.94^{a}$ & 0.50 & \multirow{4}{*}{$\Delta \mathrm{Ex}$} & $\mathrm{R}_{100} \mathrm{C}_{0}$ & $64.10^{\mathrm{a}}$ & 0.38 \\
\hline & $\mathrm{R}_{97} \mathrm{C}_{3}$ & $5.17^{\mathrm{b}}$ & 0.07 & & $\mathrm{R}_{97} \mathrm{C}_{3}$ & $62.30^{\mathrm{b}}$ & 0.38 \\
\hline & $\mathrm{R}_{94} \mathrm{C}_{6}$ & $5.98^{\mathrm{a}}$ & 0.38 & & $\mathrm{R}_{94} \mathrm{C}_{6}$ & $64.33^{\mathrm{a}}$ & 0.38 \\
\hline & $\mathrm{R}_{91} \mathrm{C}_{9}$ & $5.88^{\mathrm{a}}$ & 0.38 & & $\mathrm{R}_{91} \mathrm{C}_{9}$ & $66.02^{c}$ & 0.38 \\
\hline
\end{tabular}

$\mathrm{x}$ - the average value of the samples. $95 \%$ confidence interval for the average ANOVA. a, b, c, d- values with the same letter are not significantly different (Duncan's test). $\Delta \mathrm{Ex}$ - total color difference, $\Delta \mathrm{Ly}$ - black-white color change, $\Delta \mathrm{az}$ - red-green color change, $\Delta \mathrm{bt}$ - yellow-blue color change.

\section{The variation of $\Delta L$}

There is a significant difference between $\left(\mathrm{R}_{100} \mathrm{C}_{0}, \mathrm{R}_{94} \mathrm{C}_{6}\right),\left(\mathrm{R}_{97} \mathrm{C}_{3}\right)$, and $\left(\mathrm{R}_{91} \mathrm{C}_{9}\right)$ in the variation of $\Delta L$. The results are explained in Tab. 3. This variation decreases $1.8 \%$ for $\mathrm{R}_{97} \mathrm{C}_{3}$ according to $\mathrm{R}_{100} \mathrm{C}_{0}$. Similarly, the variation decreases $1.3 \%$ for $\mathrm{R}_{94} \mathrm{C}_{6}$ according to $\mathrm{R}_{100} \mathrm{C}_{0}$. Therefore, the variation decreases for $\mathrm{R}_{94} \mathrm{C}_{6}$. The variation increases $3.6 \%$ for $\mathrm{R}_{91} \mathrm{C}_{9}$ according to $\mathrm{R}_{100} \mathrm{C}_{0}$. Therefore, the variation increases for $\mathrm{R}_{91} \mathrm{C}_{9} . \Delta \mathrm{L}^{*}$ is the most important parameter for describing wood surface quality (Temiz et al. 2005).

\section{The variation of $\Delta a$}

There is significantly difference between $\left(\mathrm{R}_{100} \mathrm{C}_{0}, \mathrm{R}_{94} \mathrm{C}_{6}, \mathrm{R}_{91} \mathrm{C}_{9}\right)$ and $\left(\mathrm{R}_{97} \mathrm{C}_{3}\right)$ in the variation of $\Delta a$. The results are explained in Tab. 3. This variation decreases $14.9 \%$ for $\mathrm{R}_{97} \mathrm{C}_{3}$ according to $\mathrm{R}_{100} \mathrm{C}_{0}$. Similarly, the variation increases $0.7 \%$ for $\mathrm{R}_{94} \mathrm{C}_{6}$ according to $\mathrm{R}_{100} \mathrm{C}_{0}$. Therefore, the variation decreases for $\mathrm{R}_{94} \mathrm{C}_{6}$. The variation decreases $1.0 \%$ for $\mathrm{R}_{91} \mathrm{C}_{9}$ according to $\mathrm{R}_{100} \mathrm{C}_{0}$. Therefore, the variation decreases for $\mathrm{R}_{91} \mathrm{C}_{9}$.

\section{The variation of $\Delta b$}

There is a significant difference between $\left(\mathrm{R}_{100} \mathrm{C}_{0}, \mathrm{R} 94 \mathrm{C} 9\right)$ and $\left(\mathrm{R}_{97} \mathrm{C}_{3}, \mathrm{R} 91 \mathrm{C} 6\right)$ in the variation of $\Delta b$. The results are explained in Tab. 3. This variation decreases $12.0 \%$ for $\mathrm{R}_{97} \mathrm{C}_{3}$ according to $\mathrm{R}_{100} \mathrm{C}_{0}$. Similarly, the variation decreases $8.6 \%$ for $\mathrm{R}_{94} \mathrm{C}_{6}$ according to $\mathrm{R}_{100} \mathrm{C}_{0}$. Therefore, the variation decreases for $\mathrm{R}_{94} \mathrm{C}_{6}$. The variation increases $1.6 \%$ for $\mathrm{R}_{91} \mathrm{C}_{9}$ according to $\mathrm{R}_{100} \mathrm{C}_{0}$. Therefore, the variation decreases for $\mathrm{R}_{91} \mathrm{C}_{9}$.

\section{The variation of $\Delta E$}

There is significantly difference between $\left(\mathrm{R}_{100} \mathrm{C}_{0}, \mathrm{R}_{94} \mathrm{C}_{6}\right),\left(\mathrm{R}_{97} \mathrm{C}_{3}\right)$ and $\left(\mathrm{R}_{91} \mathrm{C}_{9}\right)$ in the variation of $\Delta E$. The results are explained in Tab. 3. This variation decreases $2.9 \%$ for $\mathrm{R}_{97} \mathrm{C}_{3}$ according to $\mathrm{R}_{100} \mathrm{C}_{0}$. Similarly, the variation increases $0.4 \%$ for $\mathrm{R}_{94} \mathrm{C}_{6}$ according to $\mathrm{R}_{100} \mathrm{C}_{0}$. Therefore, the variation increases for $\mathrm{R}_{94} \mathrm{C}_{6}$. The variation increase $3.0 \%$ for $\mathrm{R}_{91} \mathrm{C}_{9}$ according to $\mathrm{R}_{100} \mathrm{C}_{0}$. Therefore, the variation increases for $\mathrm{R}_{91} \mathrm{C}_{9}$. As the amount of calcite increases in MDF production, value increases. As the use rate for calcite minerals increased, the increased in the bright of boards values continued. The color and lightness differences of the MDF panels increased with increasing burned wood content (Akgül et al. 2013). Color is characterized by the wavelenghth of visible light reflected from the surface (Çakıcıer et al. 2011). 


\section{Mechanical properties}

The results of ANOVA and Duncan mean separation test for bending strength, modulus elasticity, internal bond, surface screw holding ability, Janka hardness measure vertically to the sheet surface of the fiberboards made from calcite addictive fiber and control fiberboards are shown in Tab. 4.

Tab. 4: The results of ANOVA and Duncan mean separation test for mechanical properties of the calcite addictive fiberboards and control fibreboard.

\begin{tabular}{|c|c|c|c|c|c|c|c|}
\hline \multirow{2}{*}{$\begin{array}{c}\text { Calcite } \\
\text { Board }\end{array}$} & \multirow{2}{*}{ Type } & \multirow{2}{*}{ Avg.x } & Std. & Calcite & \multirow{2}{*}{ Type } & \multirow{2}{*}{ Avg.x } & Std. \\
\hline & & & Deviation & Board & & & Deviation \\
\hline \multirow{4}{*}{$\begin{array}{c}\text { Modulus } \\
\text { elasticity } \\
(\mathrm{MOE}) \\
\left(\mathrm{N} \cdot \mathrm{mm}^{-2}\right)\end{array}$} & $\mathrm{R}_{100} \mathrm{C}_{0}$ & $3,482.91 \mathrm{c}$ & 218.21 & \multirow{4}{*}{$\begin{array}{c}\text { Surface } \\
\text { screw } \\
\text { holding } \\
\text { ability }(\mathrm{N})\end{array}$} & $\mathrm{R}_{100} \mathrm{C}_{0}$ & $10.07 \mathrm{a}$ & 0.30 \\
\hline & $\mathrm{R}_{97} \mathrm{C}_{3}$ & $3,224.16 b$ & 196.77 & & $\mathrm{R}_{97} \mathrm{C}_{3}$ & $8.77 \mathrm{~b}$ & 1.21 \\
\hline & $\mathrm{R}_{94} \mathrm{C}_{6}$ & $2,909.49 a$ & 223.48 & & $\mathrm{R}_{94} \mathrm{C}_{6}$ & $8.48 \mathrm{a}$ & 0.88 \\
\hline & $\mathrm{R}_{91} \mathrm{C}_{9}$ & $2,974.37 \mathrm{a}$ & 262.33 & & $\mathrm{R}_{91} \mathrm{C}_{9}$ & $9.30 \mathrm{ab}$ & 1.02 \\
\hline \multirow{4}{*}{$\begin{array}{l}\text { Bending } \\
\text { strength } \\
(\mathrm{MOR}) \\
\left(\mathrm{N} \cdot \mathrm{mm}^{-2}\right)\end{array}$} & $\mathrm{R}_{100} \mathrm{C}_{0}$ & $36.89 \mathrm{c}$ & 2.43 & \multirow{4}{*}{$\begin{array}{c}\text { Janka } \\
\text { hardness } \\
(\mathrm{N})\end{array}$} & $\mathrm{R}_{100} \mathrm{C}_{0}$ & $81.05 \mathrm{a}$ & 1.23 \\
\hline & $\mathrm{R}_{97} \mathrm{C}_{3}$ & $33.62 \mathrm{~b}$ & 2.78 & & $\mathrm{R}_{97} \mathrm{C}_{3}$ & $77.60 \mathrm{bc}$ & 3.11 \\
\hline & $\mathrm{R}_{94} \mathrm{C}_{6}$ & $31.30 \mathrm{a}$ & 2.42 & & $\mathrm{R}_{94} \mathrm{C}_{6}$ & $75.40 \mathrm{c}$ & 2.90 \\
\hline & $\mathrm{R}_{91} \mathrm{C}_{9}$ & $29.91 \mathrm{a}$ & 3.02 & & $\mathrm{R}_{91} \mathrm{C}_{9}$ & $78.50 \mathrm{~b}$ & 1.27 \\
\hline \multirow{4}{*}{$\begin{array}{c}\text { Internal } \\
\text { bond (IB) } \\
\left(\mathrm{N} \cdot \mathrm{mm}^{-2}\right)\end{array}$} & $\mathrm{R}_{100} \mathrm{C}_{0}$ & $0.58 \mathrm{c}$ & 0.03 & & & & \\
\hline & $\mathrm{R}_{97} \mathrm{C}_{3}$ & $0.54 \mathrm{~b}$ & 0.04 & & & & \\
\hline & $\mathrm{R}_{94} \mathrm{C}_{6}$ & $0.48 \mathrm{a}$ & 0.02 & & & & \\
\hline & $\mathrm{R}_{91} \mathrm{C}_{9}$ & $0.50 \mathrm{a}$ & 0.04 & & & & \\
\hline
\end{tabular}

$\mathrm{x}$ - the average value of the samples. $95 \%$ confidence interval for the average ANOVA. a, b, c, d - values with the same letter are not significantly different (Duncan's test).

\section{The results of the bending strength test (MOR)}

There is a significant difference between $\left(\mathrm{R}_{100} \mathrm{C}_{0}\right),\left(\mathrm{R}_{97} \mathrm{C}_{3}\right),\left(\mathrm{R}_{94} \mathrm{C}_{6}, \mathrm{R}_{91} \mathrm{C}_{9}\right)$ according to the percentage of bending strength test. The results are explained in Tab. 4 . The ratio for this test is $8.0 \%$ for $\mathrm{R}_{97} \mathrm{C}_{3}$ according to $\mathrm{R}_{100} \mathrm{C}_{0}$. Therefore, the percentage of bending strength decreases for $\mathrm{R}_{97} \mathrm{C}_{3}$. Similarly, the ratio is $19.7 \%$ for $\mathrm{R}_{94} \mathrm{C}_{6}$ according to $\mathrm{R}_{100} \mathrm{C}_{0}$. Therefore, the percentage of bending strength decreases for $\mathrm{R}_{94} \mathrm{C}_{6}$. The ratio is $17.1 \%$ for $\mathrm{R}_{91} \mathrm{C}_{9}$ according to $\mathrm{R}_{100} \mathrm{C}_{0}$. Therefore, the percentage of bending strength decreases for $\mathrm{R}_{91} \mathrm{C}_{9}$. The increase in the mineral filler content reduced the effect of interconnecting the fibers, causing MOR, MOE resistance to be adversely affected (Özdemir 2019). Tomasz et al. (2019) In the study of GCC filler addition on MDF production; The data of the 550,700 and 850 density boards showed that the bending strength (MOR) properties decreased as the filling amount increased.

\section{The results of the Internal bond (IB) test}

There is a significant difference between $\left(\mathrm{R}_{100} \mathrm{C}_{0}\right),\left(\mathrm{R}_{97} \mathrm{C}_{3}\right)$ and $\left(\mathrm{R}_{94} \mathrm{C}_{6}, \mathrm{R}_{91} \mathrm{C}_{9}\right)$ according to the percentage of internal bond (IB) test. The results are explained in Tab. 4. The ratio for this test is $7.2 \%$ for $\mathrm{R}_{97} \mathrm{C}_{3}$ according to $\mathrm{R}_{100} \mathrm{C}_{0}$. Therefore, the percentage of the internal bond decreases for $\mathrm{R}_{97} \mathrm{C}_{3}$. Similarly, the ratio is $20.0 \%$ for $\mathrm{R}_{94} \mathrm{C}_{6}$ according to $\mathrm{R}_{100} \mathrm{C}_{0}$. Therefore, the percentage of the internal bond decreases for $\mathrm{R}_{94} \mathrm{C}_{6}$. The ratio is $80.9 \%$ for $\mathrm{R}_{91} \mathrm{C}_{9}$ according to $\mathrm{R}_{100} \mathrm{C}_{0}$. Therefore, the percentage of the internal bond decreases for $\mathrm{R}_{91} \mathrm{C}_{9}$. Mineral filler type and usage rate have a negative effect on IB values (Özdemir. 2019). As the use rate for calcite minerals increased, the same results in the IB values continued. Tomasz et al. (2019) In the study 
of GCC filler addition on MDF production; The data of the 550 and 700 density boards showed that the internal bond (IB) properties decreased as the filling amount increased.

\section{The results of the modulus elasticity test (MOE)}

There is a significant difference between $\left(\mathrm{R}_{100} \mathrm{C}_{0}\right),\left(\mathrm{R}_{97} \mathrm{C}_{3}\right),\left(\mathrm{R}_{94} \mathrm{C}_{6}, \mathrm{R}_{91} \mathrm{C}_{9}\right)$ according to the percentage of modulus elasticity test. The results are explained in Tab. 4. The ratio for this test is $8.0 \%$ for $\mathrm{R}_{97} \mathrm{C}_{3}$ according to $\mathrm{R}_{100} \mathrm{C}_{0}$. Therefore, the percentage of modulus elasticity decreases for $\mathrm{R}_{97} \mathrm{C}_{3}$. Similarly, the ratio is $19.7 \%$ for $\mathrm{R}_{94} \mathrm{C}_{6}$ according to $\mathrm{R}_{100} \mathrm{C}_{0}$. Therefore, the percentage of modulus elasticity decreases for $\mathrm{R}_{94} \mathrm{C}_{6}$. The ratio is $17.1 \%$ for $\mathrm{R}_{91} \mathrm{C}_{9}$ according to $\mathrm{R}_{100} \mathrm{C}_{0}$. Therefore, the percentage of modulus elasticity decrease for $\mathrm{R}_{91} \mathrm{C}_{9}$. Mineral fillers increased the contact surface between the fibers and the glue and also created a barrier effect. It prevented the glue from being placed in the gaps and reduced the mechanical locking of the fiber and glue (Ayrilmıs et al. 2017). The intermolecular force and the sliding rubbing force between the constituents of the MDF reduced quickly rapidly, resulting in a reduced MOR and MOE (Wang et al. 2016). As the use rate for calcite minerals increased, the very little reduction result in the modulus elasticity values continued.

\section{The results of the surface screw holding ability test}

There is a significant difference between $\left(\mathrm{R}_{100} \mathrm{C}_{0}\right),\left(\mathrm{R}_{97} \mathrm{C}_{3}\right),\left(\mathrm{R}_{94} \mathrm{C}_{6}\right)$ and $\left(\mathrm{R}_{91} \mathrm{C}_{9}, \mathrm{R}_{100} \mathrm{C}_{0}\right.$, $\mathrm{R}_{97} \mathrm{C}_{3}$ ) according to the percentage of the surface screw holding ability test. The results are explained in Tab. 4. The ratio for this test is $14.8 \%$ for $\mathrm{R}_{97} \mathrm{C}_{3}$ according to $\mathrm{R}_{100} \mathrm{C}_{0}$. Therefore, the percentage of the surface screw holding ability decreases for $\mathrm{R}_{97} \mathrm{C}_{3}$. Similarly, the ratio is $14.8 \%$ for $\mathrm{R}_{94} \mathrm{C}_{6}$ according to $\mathrm{R}_{100} \mathrm{C}_{0}$. Therefore, the percentage of the surface screw holding ability decreases for $\mathrm{R}_{94} \mathrm{C}_{6}$. The ratio is $8.2 \%$ for $\mathrm{R}_{91} \mathrm{C}_{9}$ according to $\mathrm{R}_{100} \mathrm{C}_{0}$. Therefore, the percentage of the surface screw holding ability decreases for $\mathrm{R}_{91} \mathrm{C}_{9}$.

\section{The results of Janka hardness test}

There is a significant difference between $\left(\mathrm{R}_{100} \mathrm{C}_{0}\right),\left(\mathrm{R}_{97} \mathrm{C}_{3}, \mathrm{R}_{94} \mathrm{C}_{6}, \mathrm{R}_{91} \mathrm{C}_{9}\right),\left(\mathrm{R}_{94} \mathrm{C}_{6}\right)$ and $\left(\mathrm{R}_{91} \mathrm{C}_{9}\right)$ according to the percentage of Janka hardness test. The results are explained in Tab. 4. The ratio for this test decreases $4.4 \%$ for $\mathrm{R}_{97} \mathrm{C}_{3}$ according to $\mathrm{R}_{100} \mathrm{C}_{0}$. Therefore, the percentage of Janka hardness decreases for $\mathrm{R}_{97} \mathrm{C}_{3}$. Similarly, the ratio decreases $7.4 \%$ for $\mathrm{R}_{94} \mathrm{C}_{6}$ according to $\mathrm{R}_{100} \mathrm{C}_{0}$. Therefore, the percentage of the Janka hardness decrease for $\mathrm{R}_{94} \mathrm{C}_{6}$. The ratio is $17.7 \%$ for $\mathrm{R}_{91} \mathrm{C}_{9}$ according to $\mathrm{R}_{100} \mathrm{C}_{0}$. Therefore, the percentage of the Janka hardness decreases for $\mathrm{R}_{91} \mathrm{C}_{9}$. Mechanical properties including $\mathrm{MOR}, \mathrm{MOE}, \mathrm{IB}$, surface screw holding and janka hardness values of samples very little reduction result in with increasing amount of calcite minerals.

With an increase of calcite mineral interfering with wood fibers and a reduction in the surface present for creating adhesive bond with the wood fibers, a reduction in the created fiber -to- fiber glue bonds is anticipated. In this study, it is seen that mechanical test results are decreased.

\section{CONCLUSIONS}

This study evidence that MDF with up to 3\%, 6\%, 9\% wood fiber replaced by calcite mineral can be produced in MDF proses line-scale environment without significantly deteriorating the material properties. As the amount of calcite increases in MDF production, both the percentage of the TS and the percentage of the WA are increasing. This reason is the usage amount of 
calcite mineral and its geometrical structure. As the amount of calcite increases in MDF, the quality of the board surface decreases. The question to what degree wood fiber acidity compensate for the buffering capacity of calcite in a wood fibre-urea formaldehyde glue-inorganic filler system recommended to be addressed in the next studies. While the addition of calcite filler at a great number of until $3 \%$ and $6 \%$ does not have any visible effect on the MDF boards properties, at loads excessive this amount, a meaningful effect is anticipated.

As the amount of calcite increases in MDF, total color difference of the board surface increases in terms of the result of color parameters. As the amount of calcite increases in MDF, the total color difference and whiteness (black-white color change) over the surface board increase. Curative results have been obtained in physical, mechanical, color tests of calcite compounded MDF panels. Therefore, it has been determined that the use of calcite in MDF production is more appropriate in terms of productivity. A reduction in the mechanical properties and an increase in the physical properties, believed to be caused by the reduced quantity of fiber-to-fiber stress connectivity points, is most pronounced. As a result of all tests, it is suggested calcite filling mineral percentage $3 \%$ and $6 \%$ in MDF production

\section{ACKNOWLEDGEMENTS}

This study was supported by T.C. Ministry of Science Industry and Technology, Düzce University, and Divapan Integrated Wood Company as the project of San-Tez 00653.STZ.2010-2. The authors would like to acknowledge Division of Wood Chemistry and Technology Department in Faculty of Forestry at Duzce University for their help and support.

\section{REFERENCES}

1. Akgül, M., Ayrılmış, N., Çamlıbel, O., Korkut, S., 2013: Potential utilization of burned wood in manufacture of medium density fiberboard. Journal of Material Cycles and Waste Management 15(2): 195-201.

2. Akgül, M., Uner, B., Çamlibel, O., Ayata, U., 2017: Manufacture of medıum density fiberboard (MDF) panels from agribased lignocellulosic biomass. Wood Research 62(4): 615-624.

3. ANSI A 208.1, 1999: American national standard for particleboard. Composite panel association, Gaithersburg.

4. ASTM D-1037-78, 1994: Standart methods of evaluating the properties of wood-base fiber and particle panel materials.

5. ASTM D2244-07e1, 2007: Standard practice fpr calculation of calor tolerances and color differences from instrumentally measured color coordinates.

6. Ayrılmı̧̧, N., Güleç, T., Peşman, E., Kaymakcı, A., 2017: Potential use of cotton dust as filler in the production of thermoplastic composites. Journal of Composite Materials 51(30): 4147- 4155.

7. Candan, Z., Akbulut, T., Wang, S., Zhang, X., Sisci A, F., 2012: Layer thickness swell characteristics of medium density fibreboard (MDF) panels affected by some production parameters. Wood Research 57(3): 441- 452.

8. Çakıcıer, N., Korkut, S., Korkut, D. S.,Kurtoglu, A., Sönmez, A., 2011: Effect of QUV accelerated aging on surface hardness surface roughness, glossiness, and color difference for some wood species. International Journal of the Physical Sciences 6(8): 1929-1939. 
9. Çavdar, A.D., Torun, S.B., Ertas, M., Mengeloglu, F., 2019: Ammonium zeolite and ammonium phosphate applied as fire retardants for microcrystalline cellulose filled thermoplastic composites. Fire Safety Journal 107: 202-209.

10. Güller, B., 2001: Wood composites. Suleyman Demirel University Forest Faculty Journal Serial: A, Number 2: Pp 135-160.

11. Funk, M., Wimmer, R., Adamopoulos, S., 2017: Diatomaceous earth as an inorganic additive to reduce formaldehyde emissions from particleboards. Wood Material Science \& Engineering 12(2): 92-97.

12. Istek, A., Aydemir, D., Eroglu, H., 2013: Combustion properties of medium-density fiberboards coated by a mixture of calcite and various fire retardants. Turkish Journal of Agriculture and Forestry 37: 642-648.

13. Kalaycıoğlu, H., Yel, H., Çavdar A.D., 2012: Wood wool cement boards and its applications. Kastamonu University Journal of Forestry Faculty 12 (1): 122-133.

14. Kaya, N., 2018: Investigation of mechanical and physical properties of glass fiber reinforced fiber plates (MDF) produced from agricultural wastes. Journal of The Faculty of Engineering and Architecture of Gazi University 33(3): 905-916.

15. Ozyhar, T., Depnering, T., Ridgway, C., Welker, M., Schoelkopf., Mayer, I., Thoemen, H., 2020: Utilization of inorganic mineral filler material as partial replacement for wood fiber in medium density fiberboard (MDF) and its effect on material properties. European Journal of Wood and Wood Products 78(1): 75-84.

16. Özdemir, F., Ayaz, A., 2017: Investigation of the effect on combustion resistance of ammonium polyphosphate and boric acid chemicals added to surface coating. Kastamonu University. Journal of Forestry Faculty 17(2): 290-297.

17. Özdemir, F., 2019: Effect of mineral materials content as filler in medium density fiberboard. Bioresources 14(1): 2277-2286.

18. Özdemir, F., Tutus, A., 2016: Effects of coating with calcite together with various fire retardants on the fire properties of particle- board. BioResources 11: 6407-6415.

19. Salari, A., Tabarsa T., Khazaeian A., Saraeian A., 2012: Effect of nanoclay on some applied properties of oriented strand board (OSB) made from underutilized low quality paulownia (Paulownia fortunei) wood. Journal of Wood Science 58: 513-524.

20. Taghiyari, H.R., Nouri, P., 2015: Effects of nano-wollastonite on physical and mechanical properties of medium-density fiberboard. Maderas: Ciencia Y Tecnología 17 (4): 833-842.

21. Taghiyari, H.R., Behrooz, M.P., Morrell, J.J., 2016: Effects of wollastonite on the properties of medium-density fiberboard (MDF) made from wood fibers and camel-thorn Maderas. Ciencia Y Tecnología 18(1): 157 - 166.

22. Temiz, A., Yildiz, U.C., Aydin, I., Eikenes, M., Alfredsen, G., Colakoglu, G., 2005: Surface roughness and color characteristics of wood treated with preservatives after accelerated weathering test. Applied Surface Science 250(1-4): 35-42.

23. TS EN 310, 2008: Wood-based-panels determination of modulus of elasticity in bending and of bending strength.

24. TS EN 317, 2008: This standard specifies a method of determining the swelling in thickness of flat pressed or drum pressed particleboards, fibreboards and cement bonded particleboards.

25. TS EN 319, 2008: Particleboards and fibreboards determination of tensile strength perpendicular to the plane of the board.

26. TS EN 323, 2008: Wood-based-panels determination of density.

27. TS EN 325, 2008: Wood-based-panels determination of dimensions of test pieces. 
28. TS EN 326-1, 1999: Wood-based-panels sampling, cutting and inspection-part 1: Sampling test pieces and expression of test results.

29. TS EN 382-1, 1999: Fiberboards- determination of surface absorption part 1: Test method for dry process fibreboards.

30. TS EN 622-5, 2008: Fibreboards-specifications-part-5 Requirements for dry process boards (MDF).

31. Wang, J., Wang, F., Gao, Z., Zheng, M., Sun, J., 2016: Flame retardant medium-density fiberboard with expanded vermiculite. Bioresources 11(3): 6940-6947.

32. Xing, C., Zhang, S.Y., Deng, J., Riedl, B., Cloutier, A., 2006: Medium-density fiberboard performance as affected by wood fiber acidity, bulk density, and size distribution. Wood Science and Technology 40: 637-646.

33. Zahedsheijani, R., Gholamiya, H., Tarmia, A., Yousefi, H., 2011: Mass transfer in medium density fiberboard (MDF) modified by $\mathrm{Na}+$ montmorillonite $(\mathrm{Na}+\mathrm{Mmt})$ nanoclay, Maderas. Ciencia Y Tecnología 13(2): 163-172.

\author{
Osman Camlibel \\ KirikKale University \\ Kirikkale Vocational School \\ Interior Design Program \\ Yahsihan, KirikKale \\ TURKeY
}

*Corresponding author: osmancamlibel@kku.edu.tr

Mehmet Akgul

Karamanoglu Mehmetbey University

Yunus Emre Campus, 70100

KaRAMAN

Turkey 
